\title{
QUALITY OF WORKLIFE FROM AN EMPLOYEE PERSPECTIVE: A REVIEW BASED ON AUTOMOBILE INDUSTRY
}

\author{
* Dr. Mallikarjuna N.L
}

\begin{abstract}
Quality of Work Life (QWL) provides a balanced relationship among work, non-work and family aspects of life. This study aims to determine how quality of work life influences the employee's satisfaction level. The sample size is 110 respondents, the research type used for the study is descriptive research and the sampling technique is convenience sampling. The tools used in the study are Percentage analysis, Chi-Square test, Average Score Analysis for interpreting the data for Quality of Work life of employees in the Automobile Sector. The findings of the study suggest that the impact of QWL is enriched when the factors like "Working Environment, Up-Gradation of Skill \& Knowledge, and Social Integration of the Company" are considered.
\end{abstract}

Keywords: Quality of work life, Automobile Industry.

\section{INTRODUCTION}

Quality of work life (QWL) helps the organizations to recognize employee's responsibilities to develop jobs and working conditions that are excellent for people as well as for economic health of the organization. The work-life balance between workers and managers plays an important role in the present scenario. The Automobile industry is a very large market in India. Previously the automobile industry was the fastest growing industry globally but in the current scenario it is experiencing a flat or negative growth.

QWL determines how employees satisfy their personal and working needs by actively participating in workplace. QWL has been found to influence the commitment and productivity of employees in the industries (D.Vijaylakshmi, V.Loganayaki, 2013).

The quality of work life (QWL) is a broad terminology which covers variety of concepts and theories through which the job profiles are designed in such a way that they grant employees more responsibility and authority. It is a comprehensive, department-wide program designated to improve employee satisfaction, strengthening workplace learning. A high quality of work life is important for organizations to continue, to attract and hold employees (Sandrick, 2003).

Factors which contribute to QWL include adequate and fair remuneration, safe and healthy

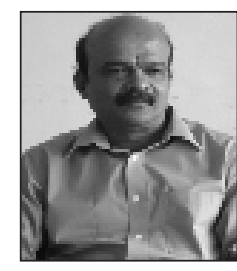

\section{*Dr. Mallikarjuna N.L}

Associate Professor

Karnataka State Womens' University

Mandya 
working conditions and social integration in the work environment of the organization that enables an individual to develop and use all his or her capacities. It reveals that employees are the most important assets of the organization as they are truthful, responsible and capable of making great contribution. They should be treated with nobility and honour. (Straw, R.J. and C.C. Heckscher, 1984)

Factor credentials boosting Quality of Work Life of BSNL Employees in Jammu Region says that the satisfaction level among the employees are high in various factors such as income and fair compensation, safe and healthy working conditions, opportunities to use and develop human capacity, opportunity for career growth, social integration in the work force, constitutionalism in work organisation, eminence of work life and social relevance of work (Dr.Meenakshi Gupta... 2011)

A Study on Quality of Work life among Workers with special reference to Automobile Industry in Bangalore District - An automobile hub reveals that an employee who is happier and healthy will give better productivity, take better decisions and contribute in a positive way to organizational goal. Quality of work life can affect various factors such as the timing of employees, productivity, leaves availed etc., Work life balance should be maintained in an effective manner to ensure that most of the employees are at high potential and are stress free (Indumathy. R \& Kamal Raj. S ...2012)

\section{OBJECTIVES OF THE STUDY}

The study aims at analyzing the Quality of work life of employees in Automobile sector. In this study the Quality of work life of employees are analysed based on the factors such as Working environment, Up gradation of knowledge and skill and social integration in Automobile sector.

\section{RESEARCH METHODOLOGY:}

This study is of descriptive research and the sampling technique used for the study is nonprobability convenience sampling technique for collecting primary data from 110 respondents. The tools used in this study are Percentage analysis, Chi- Square test, Average Score Analysis.

\section{RESULT AND DISCUSSION:}

Table 1: Showing the age wise classification of respondents

\begin{tabular}{|l|l|l|}
\hline Age & $\begin{array}{l}\text { No. of } \\
\text { Respondents }\end{array}$ & Percentage \\
\hline $20-30$ & 16 & 14.5 \\
\hline $31-40$ & 26 & 23.7 \\
\hline $41-50$ & 45 & 40.9 \\
\hline Above 50 & 23 & 20.9 \\
\hline Total & 110 & 100 \\
\hline
\end{tabular}

INTERPRETATION: From the above table it is observed that majority of the employees belong to the age group of 41-50 i.e., $40.9 \%$. $23.7 \%$ of employees belong to the age group of $31-40$ and $20.9 \%$ of employees belong to the age group above 50 .

\section{Table 2: Showing the Gender wise} classification of respondents

\begin{tabular}{|c|l|l|l|}
\hline Sl.no & Gender & $\begin{array}{l}\text { No. of } \\
\text { Respondents }\end{array}$ & Percentage \\
\hline 1 & Male & 63 & 57.27 \\
\hline 2 & Female & 47 & 42.73 \\
\hline 3 & Total & 110 & 100 \\
\hline
\end{tabular}




\section{INTERPRETATION}

From the above table it is observed that 57.27 percent of the respondents are male and 42.73 percent of the respondents are female. Therefore it is concluded that comparatively male employees are more than female employees since it is an automobile sector.

Table 3: Showing the opinion of respondent about Working Environments

\begin{tabular}{|l|l|l|l|l|l|l|l|l|l|l|}
\hline Content & SA & $\%$ & $\mathrm{~A}$ & $\%$ & $\mathrm{~N}$ & $\%$ & $\mathrm{D}$ & $\%$ & $\mathrm{SD}$ & $\%$ \\
\hline $\begin{array}{l}\text { Working environment } \\
\text { is pleasant in the } \\
\text { department }\end{array}$ & 50 & 45.4 & 22 & 20.0 & 19 & 17.2 & 10 & 9.0 & 9 & 8.1 \\
\hline $\begin{array}{l}\text { Satisfied with the } \\
\text { infrastructure provided } \\
\text { by the company }\end{array}$ & 18 & 16.3 & 46 & 41.8 & 31 & 28.1 & 12 & 10.9 & 3 & 2.7 \\
\hline $\begin{array}{l}\text { Interpersonal } \\
\text { relationship between } \\
\text { the colleagues }\end{array}$ & 28 & 25.4 & 45 & 40.9 & 20 & 18.1 & 9 & 8.1 & 8 & 7.2 \\
\hline $\begin{array}{l}\text { Interpersonal } \\
\text { relationship between } \\
\text { the superiors. }\end{array}$ & 25 & 22.7 & 37 & 33.6 & 25 & 22.7 & 14 & 12.7 & 9 & 8.1 \\
\hline $\begin{array}{l}\text { Satisfied with the } \\
\text { leave status provided } \\
\text { by the company. }\end{array}$ & 34 & 30.9 & 28 & 25.4 & 28 & 25.4 & 13 & 11.8 & 7 & 6.3 \\
\hline
\end{tabular}

\section{INTERPRETATION}

It is inferred that $45.45 \%$ of employees strongly agree with the working environment and $30.91 \%$ of employees strongly agree with the leave status. $40.91 \%$ of employees agreed in interpersonal relationship between colleagues, $33.64 \%$ of employees agreed in interpersonal relationship between the superiors. 
Table 4: Showing the role of working environment in Up gradaing the knowledge and skill of respondents

\begin{tabular}{|c|c|c|c|c|c|c|c|c|c|c|c|}
\hline Sl.No. & Content & SA & $\%$ & A & $\%$ & $\mathrm{~N}$ & $\%$ & $\mathrm{D}$ & $\%$ & SD & $\%$ \\
\hline 1 & $\begin{array}{l}\text { Working experience } \\
\text { provided by the company } \\
\text { improves my ability }\end{array}$ & 41 & 37.2 & 27 & 24.5 & 23 & 20.9 & 17 & 15.4 & 2 & 1.8 \\
\hline 2 & $\begin{array}{l}\text { My experience in particular } \\
\text { field have been utilized by } \\
\text { the company }\end{array}$ & 11 & 10.0 & 46 & 41.8 & 37 & 33.6 & 10 & 9.0 & 6 & 5.4 \\
\hline 3 & $\begin{array}{l}\text { My company recognizes } \\
\text { and acknowledges for } \\
\text { individual interest and } \\
\text { potentialities }\end{array}$ & 25 & 22.7 & 39 & 35.4 & 24 & 21.8 & 17 & 15.4 & 5 & 4.5 \\
\hline 4 & $\begin{array}{l}\text { I am satisfied with the } \\
\text { promotion process }\end{array}$ & 11 & 10.0 & 35 & 31.8 & 15 & 13.6 & 32 & 29.0 & 17 & 15.4 \\
\hline 5 & $\begin{array}{l}\text { My company conducts } \\
\text { internal seminar and } \\
\text { conferences to facilitate } \\
\text { employee learning and } \\
\text { development }\end{array}$ & 15 & 13.6 & 45 & 40.9 & 26 & 23.6 & 14 & 12.7 & 10 & 9.0 \\
\hline 6 & $\begin{array}{l}\text { The company provides the } \\
\text { opportunity for my career } \\
\text { development }\end{array}$ & 21 & 19.0 & 34 & 30.9 & 35 & 31.8 & 17 & 15.4 & 3 & 2.7 \\
\hline 7 & $\begin{array}{l}\text { I am satisfied with the } \\
\text { recruitment process }\end{array}$ & 12 & 10.9 & 34 & 30.9 & 16 & 14.5 & 24 & 21.8 & 24 & 21.8 \\
\hline
\end{tabular}

\section{INTERPRETATION}

From the above table it is inferred that $37.2 \%$ of employees strongly agree that work experience is an important factor for up gradation of knowledge and skill, $41.8 \%$ of employees agree that utilizing the knowledge and skill in a proper way is most important and $40.9 \%$ of employees agree that up gradation of knowledge and skill can be effective through conducting seminars for employees. 
Table 5: Showing the Average score analysis for level of satisfaction in Working environment with respect to Age

\begin{tabular}{|l|l|l|l|l|}
\hline \multirow{2}{*}{ Factors } & \multicolumn{2}{l|}{ Age } \\
\cline { 2 - 6 } & $\begin{array}{l}20-30 \\
\text { Years }\end{array}$ & $\begin{array}{l}30-40 \\
\text { Years }\end{array}$ & $\begin{array}{l}40-50 \\
\text { Years }\end{array}$ & $\begin{array}{l}\text { Above } \\
50 \text { Years }\end{array}$ \\
\hline $\begin{array}{l}\text { Working environment is pleasant in the } \\
\text { department }\end{array}$ & 3.69 & 3.73 & 4.00 & 3.83 \\
\hline $\begin{array}{l}\text { Satisfied with the infrastructure provided by } \\
\text { the company }\end{array}$ & 3.63 & 3.73 & 3.60 & 3.35 \\
\hline $\begin{array}{l}\text { Interpersonal relationship between the } \\
\text { colleagues }\end{array}$ & 3.63 & 3.58 & 3.69 & 3.87 \\
\hline $\begin{array}{l}\text { Interpersonal relationship between the } \\
\text { superiors. }\end{array}$ & 3.06 & 3.69 & 3.51 & 3.57 \\
\hline $\begin{array}{l}\text { Satisfied with the leave status provided by the } \\
\text { company. }\end{array}$ & 4.00 & 3.50 & 3.67 & 3.43 \\
\hline
\end{tabular}

\section{INTERPRETATION}

It is observed from the above table that in the average score analysis, employees belonging to the age group 20-30 years have the high average score for the leave status provided by the company and employees belonging to the age group 40-50years have the high average score for pleasant working environment.

Table 6: Chi-square test showing the association between the Gender and Social Integration in the Company

H0: There is no significant difference between Gender and Social Integration in the Company.

H1: There is a significant difference between Gender and Social Integration in the Company.

\begin{tabular}{|l|l|l|l|}
\hline \multicolumn{1}{|c|}{ Factors } & $\begin{array}{l}\text { Chi-Square } \\
\text { Value }\end{array}$ & P-Value & Significant \\
\hline Recognize my own capabilities & 9.078 & .084 & NS \\
\hline $\begin{array}{l}\text { Innovative ideas are being appreciated by the } \\
\text { management }\end{array}$ & 2.165 & .826 & NS \\
\hline
\end{tabular}




\begin{tabular}{|l|l|l|l|}
\hline $\begin{array}{l}\text { Information regarding changes in the } \\
\text { organization is brought to my knowledge. }\end{array}$ & 6.949 & .224 & NS \\
\hline Motivated by superiors & 7.561 & .182 & NS \\
\hline $\begin{array}{l}\text { Like to serve in the same organization until my } \\
\text { retirement. }\end{array}$ & 11.077 & .086 & NS \\
\hline Satisfied with the grievance process & 5.357 & .374 & NS \\
\hline
\end{tabular}

S-Significant, NS-Not Significant, P-Probability (P value $\leq \quad 0.05$ )

INFERENCE: From the above table it is inferred that all the above factors of social integration in the company have no significant influence with gender.

Table 7: Chi-square test showing the association between the Education Qualification and working environment

Hypothesis Testing :

H0: There is no significant difference between Education Qualification and working environment.

H1: There is a significant difference between Education Qualification and working environment

\begin{tabular}{|l|l|l|l|}
\hline Factors & $\begin{array}{l}\text { Chi-Square } \\
\text { Value }\end{array}$ & P-Value & Significant \\
\hline $\begin{array}{l}\text { Working environment is } \\
\text { pleasant in the department }\end{array}$ & 54.644 & .000 & S \\
\hline $\begin{array}{l}\text { Satisfied wi the } \\
\text { infrastructure provided by the } \\
\text { company }\end{array}$ & 11.501 & .487 & NS \\
\hline $\begin{array}{l}\text { Interpersonal relationship } \\
\text { between the colleagues }\end{array}$ & 18.891 & .091 & NS \\
\hline $\begin{array}{l}\text { Interpersonal relationship } \\
\text { between the superiors. }\end{array}$ & 33.594 & .001 & S \\
\hline $\begin{array}{l}\text { Satisfied with the leave status } \\
\text { provided by the company. }\end{array}$ & 9.900 & .625 & NS \\
\hline
\end{tabular}

S-Significant, NS-Not Significant, P-Probability (P value $\leq \quad 0.05$ ) 


\section{INFERENCE:}

From the above table it is inferred that two factors pleasant working environment and interpersonal relationship between the superiors have significant association with the educational qualification.

\section{CONCLUSION:}

The quality of work life plays an important role in every organization. The study on quality of work life has an objective to measure the employee's perception towards the organization. This study reveals that many respondents have opined that the working environment is pleasant in automobile industry. They also agreed that facilities provided by the organizations in automobile sector are sufficient. Education qualification has a significant influence in recognizing their capabilities. Almost all factors considered to measure the quality of work life of employees gives satisfactory report from employee's perception in Automobile sector.

\section{REFERENCES:}

- D.Vijaylakshmi, V.Loganayaki, (2013) A Study On Quality Of Worklife at Telecom Industries with special reference to
Karnataka. International Journal of Management Focus . ISSN 22502971.

Sandrick K., (2003), "Putting the emphasis on employees as an award. Winning employer, Baptist health care has distant memories of the workforce shortage", Trustee, January, pp. 6-10

- Dr. Meenakshi Gupta, (2011) Factor Credentials Boosting Quality Of Work Life Of Bsnl Employees In Jammu Region. ISSN 2229-4104. Volume 2, Issue 1.

Indumathy.R, Kamalraj.S, (2012) A Study On Quality Of Worklife Among Workers With Special Reference To Textile Industry In Tirupur District - A Textile $\mathrm{Hub}$. International Journal of Multidisciplinary Research. ISSN 2231 5780. Volume 2, Issue 4.

Straw, R.J. and C.C. Heckscher, 1984. QWL: New working relationships in the Communication industry. Labor Studies J., Vol. 9: 261-274 